\title{
Microbial Degradation of Livestock-Generated Ammonia Using Biofilters at Typical Ambient Temperatures
}

\author{
A. E. Kalingan, Chung-Min Liao, * Jein-Wen Chen, and Szu-Chieh Chen \\ Department of Bioenvironmental Systems Engineering, \\ National Taiwan University, Taipei, Taiwan, Republic of China
}

\begin{abstract}
The purpose of this research was to neutralize livestock-generated ammonia by using biofilters packed with inexpensive inorganic and organic packing material combined with multicultural microbial load at typical ambient temperatures. Peat and inorganic supporting materials were used as biofiltration matrix packed in a perfusion column through which gas was transfused. Results show the ammonia removal significantly fell in between 99 and $100 \%$ when ammonia concentration of $200 \mathrm{ppmv}$ was used at different gas flow rates ranged from 0.030 to $0.060 \mathrm{~m}^{3} \mathrm{~h}^{-1}$ at a fluctuating room temperature of $27.5 \pm 4.5^{\circ} \mathrm{C}$ (Mean $\pm \mathrm{SD}$ ). Under these conditions, the emission concentration of ammonia that is liberated after biofiltration is less than $1 \mathrm{ppmv}\left(0.707 \mathrm{mg} \mathrm{m}^{-3}\right)$ over the period of our study, suggesting the usage of low-cost biofiltration systems for long-term function is effective at wider ranges of temperature fluctuations. The maximum $(100 \%)$ ammonia removal efficiency was obtained in this biofilter was having an elimination capacity of $2.217 \mathrm{~g} \mathrm{~m}^{-3} \mathrm{~h}^{-1}$. This biofilter had high nitrification efficiencies and hence controlled ammonia levels with the reduced backpressure.
\end{abstract}

*Correspondence: A. E. Kalingan, Department of Bioenvironmental Systems Engineering, National Taiwan University, Taipei, Taiwan 10617, Republic of China; E-mail: cmliao@ccms.ntu.edu.tw. 
The response of this biofilter to shut down and start up operation showed that the biofilm has a superior stability.

Key Words: Biofilter; Ammonia; Degradation.

\section{INTRODUCTION}

Odor emissions from intensive livestock operations originate from three main sources: field application of animal waste, animal rearing building, and manure treatment on holding facilities. There are more than 130 major and minor gas pollutants in animal houses in general and swine house in particular. ${ }^{[1]}$

Ammonia, hydrogen sulfide and carbon dioxide are the three main pollutants released from swine house facilities. ${ }^{[2]}$ Ammonia is one of the gases produced in greatest volume from swine waste causing one of the biggest pollution problems in swine farming. This cannot be avoidable due to the absence of phytase (needed to digest phosphorus) in their digestive and assimilatory systems. This undigested phosphorus is deposited on farm soil as fertilizer resulting in environmental pollution leading to malodor. Approximately $50 \%$ of the ammonia production from swine production units is from swine housing and slurry storage. During summer and winter the ammonia emitted from swine house per animal per day is approximately 8.7 and $6.2 \mathrm{~g}$, respectively. ${ }^{[3]}$ Reductions in ammonia emissions by 28 to $79 \%$ through diet modifications have also been reported. ${ }^{[4]}$ Countries like Taiwan where land is scarce and hog farming is intensive face a major malodor threat. Taiwan's swine production (19.07\%) in 1999 was estimated to be nearly 61.5 billion NT dollars worth when compared to other livestock products $(39.44 \%){ }^{[5]}$

A survey of about 8000 randomly selected farmers in some European countries demonstrated that hog farmers are at the highest risk (27.3\%) among agricultural workers for the development of work related respiratory symptoms. ${ }^{[6]}$ It was estimated that at least $60 \%$ of swine confinement workers have acute or sub-acute respiratory symptoms that include dry cough chest tightness and wheezing on exposure to the work environment; irritation of the nose, eye, throat and stuffy nose due to poor air quality. ${ }^{[7]}$ To alleviate the environmental impact and to defend public and animal health, appropriate air pollution control technology is to be recognized. In comparison with conventional, emanation control measures such as absorption, adsorption, condensation, incineration, multicellular-cyclones, electrostaticprecipitations, neutralization, microbiological assimilation of ammonia appears lucrative and approachable to deal with. Microbiological assimilation takes place in an enclosed reactors (biofilters) under process optimized conditions. ${ }^{[8]}$

Biofiltration is an air pollution control technology where waste malodorous gas is treated by passing through a microbiologically active porous packing material. The selection of the (a) type of packing material, (b) microbial load and their viability, (c) optimum moisture content, and (d) process time and temperature determine the efficacy of the neutralization process and the elimination of their respective malodor. Biofilters have neutralized the emission of alcohols, ethers, aldehydes, ketones, monocyclic aromatics organic amines, and sulphides at an equitable concentration. Biofiltration of ammonia has been evaluated using 
heterotrophic bacteria Arthrobacter oxydans CH8, (isolated from hog waste water lagoon) and in comparison with Nitrosomonas europaea performed better in treating elevated concentrations of ammonia. ${ }^{[9-11]}$ Chung $^{[12]}$ reported the usage of co-immobilized bacterial cells in removing hydrogen sulfide and ammonia together at appropriate proportions.

Heber et al. ${ }^{[13]}$ measured the daily mean ammonia concentrations between 2.0 and $13.7 \mathrm{ppm}$ in four mechanically ventilated swine houses and between 2.7 and $14.4 \mathrm{ppm}$ in four naturally-ventilated swine houses. Peak ammonia concentration in swine houses, however, may exceed $30 \mathrm{ppm}$ in wintertime with poor ventilation. $\mathrm{Ni}$ et al. ${ }^{[14]}$ explained that, at the initial stage of ammonia release induced by the high ventilation, the high release of $\mathrm{CO}_{2}$ gradually raised the $\mathrm{pH}$ in the surface manure in the swine house. The increased $\mathrm{pH}$ accelerated the release of ammonia. The higher release of ammonia, had a negative feedback to the $\mathrm{pH}$ of the slurry.

In Taiwan, the EPA has set an ambient air standard at $1 \mathrm{ppm}$ for ammonia. To attain this stipulated specifications and impending higher specifications in future, the vent exhaust of animal houses must gratify the existing EPA specifications in Taiwan and in their respective countries. In view of these stringent control measures, continuous improvement in selecting packing materials, microbial load, and gaining control over the process parameters are considered highly necessary. The objective of this investigation was to determine the performance and the removal efficiency of a low-cost continuously operated biofilter at a relatively high ammonia inlet concentration in a typical ambient temperature condition and the operation dynamic of the packed bed reactor system over long durations.

\section{MATERIALS AND METHODS}

\section{Organism and Culture Medium}

To gain access to a wide range of chemoautotrophic bacteria particularly the ammonia oxidizing bacteria (Nitrosomonas, Nitrosospira, Nitrosococcus, Nitrosolobus, and Nitrosovibrio) and the nitrite-oxidizing bacteria, soil harboring activated sludge from animal house facility was collected. Cells were harvested washed and transferred in LB Medium consisting of tryptone 1\%; yeast extract $0.5 \% ; \mathrm{NaCl} 0.5 \%$ (for enrichment); aerated heavily under agitation in 200-rpm orbital shaker at $25^{\circ} \mathrm{C}$ for $48 \mathrm{~h}$. Since effective ammonia oxidation takes place at a $\mathrm{pH}$ above 7.5, we acclimated these microbes by maintaining their growth at a $\mathrm{pH}$ of 7.5 to increase their efficiency. Effect of nitrite on ammonia-oxidizing bacteria (AOB) suggests an ecological advantage for ammonia oxidizers to grow in consortia with nitrite-oxidizing bacteria (NOB). The growth and decay of AOB supplies nitrite and organic compounds that can serve as growth substrates for NOB and heterotrophic bacteria, respectively. Hence, ammonia oxidizers may be able to initiate biofilm formation in ammoniated distribution systems and provide conditions amenable to the development of a diverse microbial community aiding effective ammonia degradation. 


\section{Filter Materials}

To support the growth of a wide range of chemoautotrophic bacteria, peat moss (91\% organic) was selected. Perlite (inorganic) and vermiculite (inorganic) were incorporated to provide high aeration and water retention for long durations, respectively. This combination was preferred to eliminate the addition of water at frequent intervals, which is necessary to maintain adequate moisture content in the biofilter. Both supporting inert inorganic material serves to increase the bed porosity and to ensure more homogenous gas distribution across the perfusion column.

Keeping this in view, two types of packing material for the biofilter was meticulously designed. First reactor was designed to hold a mixture of peat moss, perlite (Number 3) and vermiculite (Number 2) at a ratio 3:1:1. The second reactor was designed to hold a mixture of peat moss and polystyrene beads of less than $3 \mathrm{~mm}$ size in the ratio 3:2. Chemoautotrophic bacteria obtained from activated sludge were harvested in buffered LB Medium ( $\mathrm{pH} 7.5)$, mixed with filter material and packed in both the perfusion columns (reactors) simultaneously.

\section{Experimental Setup}

Aerobic up flow biofilter was used in our study. The schematic set-up of experiment was shown in Fig. 1. The perfusion column is made up of transparent polyacrylic tube with an internal diameter of $5 \mathrm{~cm}$. The perfusion column was packed to height of $50 \mathrm{~cm}$. The filter material was supported by a perforated plate at the bottom through which the gas was evenly distributed. One sampling port drilled on

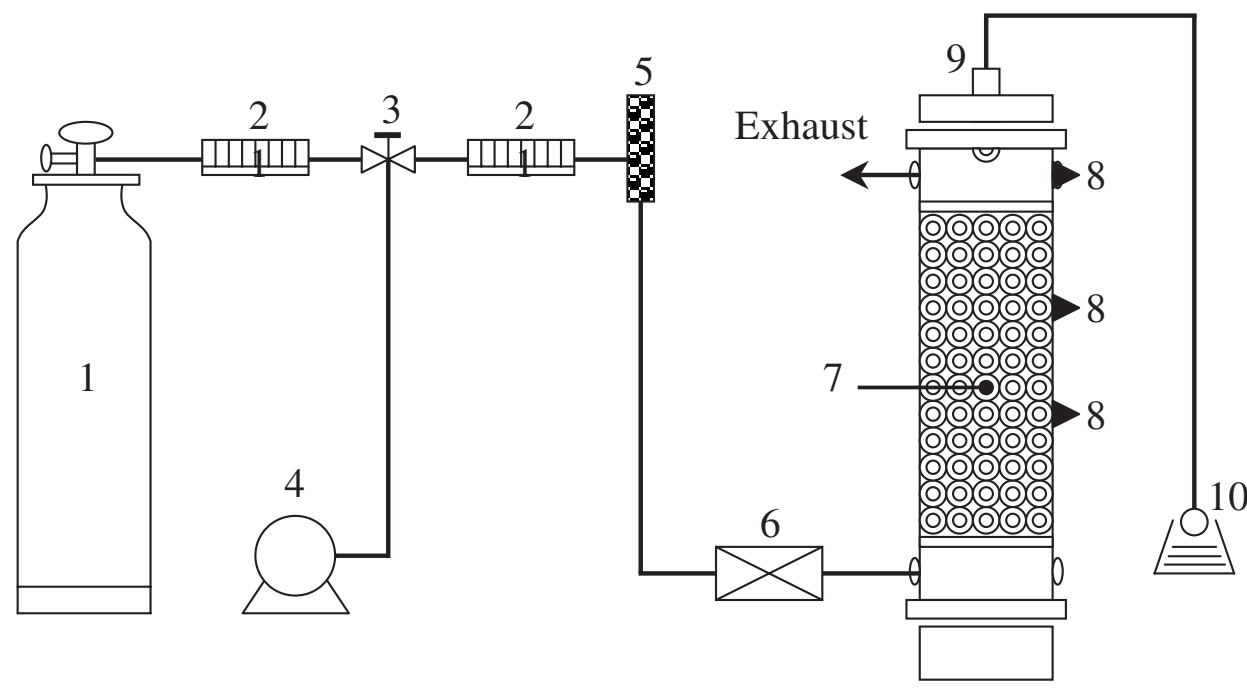

Figure 1. Schematic diagram of the biofilter system: (1) $\mathrm{NH}_{3}$ gas cylinder, (2) flow meter, (3) air valve, (4) air compressor, (5) air filter, (6) inlet chamber, (7) packing material, (8) sampling port, (9) spray nozzle, (10) peristaltic pump. 
the perfusion column on the top was sealed by soft polyvinyl chloride septa mend for outlet gas analysis. Ammonia was passed through the packed bed at different flow rates and at different biofilter height. Concentrations of gas samples were analyzed from inlet and outlet ports at different time intervals. Although humidification of waste gas is considered most critical for effective treatment, here it was not considered necessary due to the inability of ammonia in stripping moisture from the supporting material. This bioprocess was investigated at fluctuating room temperatures of $23-32^{\circ} \mathrm{C}$.

\section{Analytical Methods}

Ammonia gas concentrations were analyzed using portable ammonia detector (GfG, Dortmund, Germany) at room temperature. The retention time of ammonia was less than a second.

\section{RESULTS AND DISCUSSION}

\section{General Results}

The physical and chemical properties of the filter bed material are presented in Table 1. The nutrients presented in the filter supported the growth of the microorganisms partially.

During the start-up, both the reactors were inoculated with activated sludge containing a mixed population of microorganisms. In order to support the growth of the microorganisms within the packed bed, filtered airflow at $60 \mathrm{Lh}^{-1}$, was continuously provided for $48 \mathrm{~h}$ through a compressor to both the reactors to achieve

Table 1. Physical and chemical properties of the biofilter materials.

\begin{tabular}{lc}
\hline Property & Range \\
\hline Coarseness & $<20 \mathrm{~mm} \mathrm{particles}^{-3}$ \\
Density & $178 \mathrm{~kg} \mathrm{~m}^{-3}$ \\
Moisture content & $60-70 \%$ \\
$\mathrm{pH}$ & 7.5 \\
Carbon content & $45 \%$ \\
Nitrate nitrogen & $2.5 \%$ \\
Ammonium nitrogen & $7.5 \%$ \\
Phosphorous & $8 \%$ \\
Potassium & $16 \%$ \\
Total sulfur & $0.03 \%$ \\
Water capacity & $74 \%$ \\
Volume of pores & $95 \%$ \\
Water retention & $9 \mathrm{~g} \mathrm{~g}^{-1}$ \\
\hline
\end{tabular}




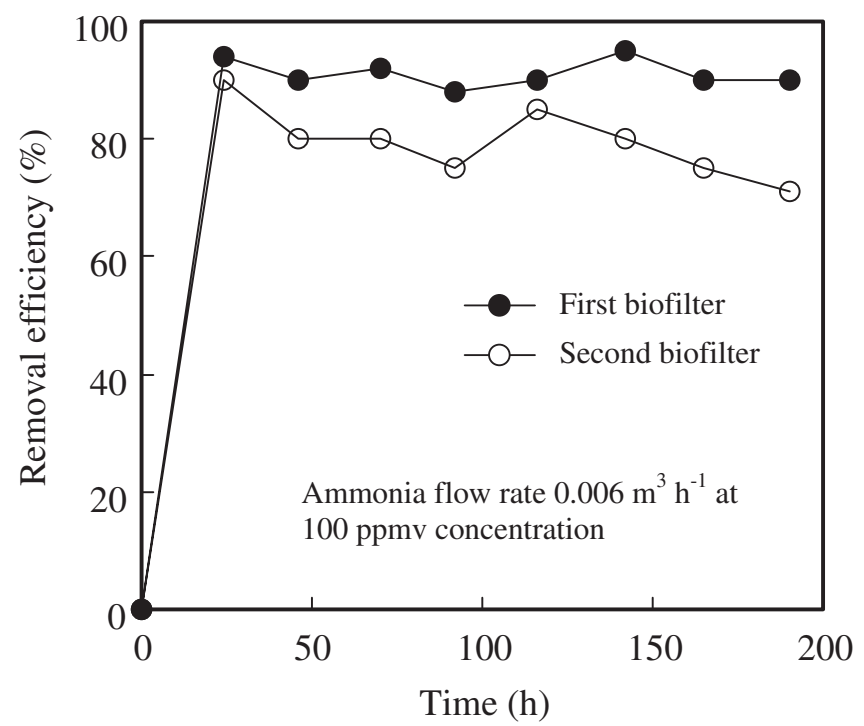

Figure 2. Steady state performance of the biofilters (first biofilter: peat, perlite, and vermiculite; second biofilter: peat and polystyrene spheres) both having a filter bed height of $50 \mathrm{~cm}$ in between 23 and $32^{\circ} \mathrm{C}$.

partial growth. In order to acclimatize the microbial population, ammonia at a concentration of $100 \mathrm{ppmv}$ was transfused at $0.0060 \mathrm{~m}^{3} \mathrm{~h}^{-1}$ through the reactors for a period of 5 days. Gradually the microbial population grew and complete biomass growth was achieved within 20 days perfect enough to distinguish between uninoculated and inoculated biofilters. Distinctive performance of the two reactors show the attainment of stabilized state with high removal efficiency of ammonia, which manifests high microbiological activity in the filter (Fig. 2).

Since our aim was to imitate an ongoing natural emission process from livestock facilities where fluctuation in temperature and flow velocity in ammonia emission is inevitable, we neither heated nor cooled ammonia before treatment; although it is considered the most critical in pretreatment process. Also considering the fact that animal responses at 100 to $200 \mathrm{ppm}$ induces sneezing, salivation and loss of appetite followed by respiratory diseases, an inlet concentration of $200 \mathrm{ppmv}$ of ammonia at a flow rate $500 \mathrm{cc}$ per minute was considered vital for our investigation. Based on earlier reports and comparing other VOC removal, we selected four different perfusion column (bed) heights for our investigations: $20,30,40$, and $50 \mathrm{~cm}$.

\section{Effects of Filter Bed Type}

Peat, Perlite, and Vermiculite

The typical performance of the bed type of biofilter containing peat, perlite and vermiculite, where the removal efficiencies are plotted against the depth of the 


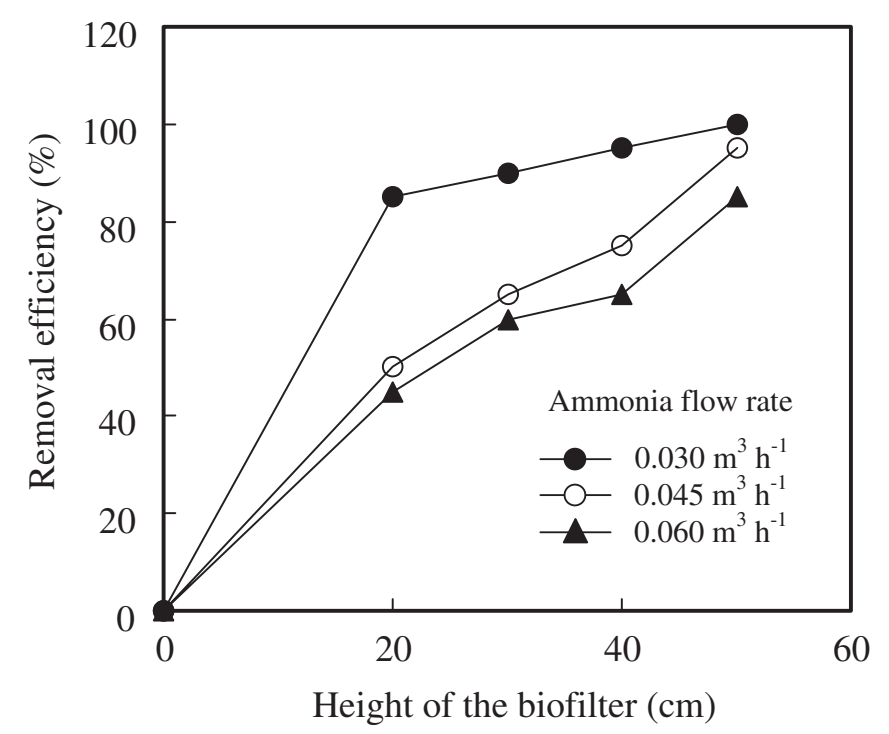

Figure 3. Removal efficiency of the first biofilter (peat, perlite, and vermiculite) at different bed heights for $200 \mathrm{ppmv}$ ammonia in between 23 and $32^{\circ} \mathrm{C}$.

biofilter is shown in Fig. 3. The removal efficiency showed a distinct variation along the height of the filter. Removal efficiency in the biofilter is mainly controlled by the mass transfer rate of the substrate in the biofilm and in the gas phase boundary layer, which in turn is controlled by the residence time (RT) in the biofilter. At high gas flow rates the RT being inadequate; the removal efficiency did not remarkably decrease indicating biodegradation constraint of the biofilm. At a gas concentration of $200 \mathrm{ppmv}$ with flow velocity of $0.030 \mathrm{~m}^{3} \mathrm{~h}^{-1}$ when passed through a bed height of $50 \mathrm{~cm}$ eliminated ammonia completely indicating a highly efficient consortium of microbial population mainly consisting of ammonia oxidizers and nitrite oxidizers were actively degrading ammonia sufficient to correspond the gas flow velocity.

Only $80 \%$ removal was achieved at a gas flow rate of $0.060 \mathrm{~m}^{3} \mathrm{~h}^{-1}$ at the same bed height indicating the removal efficiency had decreased rapidly with an increase in the gas flow velocity. Reduction in removal efficiency could be due to the uneven microbial growth and their non-uniform catalytic activity along the height of the filter bed or accumulation and/or secretion of toxic/acidic intermediates leading to a change in the buffering capacity of the biofilter. Hodge and Devinny ${ }^{[16]}$ have confirmed the formation of organic acids in the biofilter.

As the empty bed retention time (EBRT) reduced gradually during three different gas flow rates it had significant effects on ammonia removal, which can be attributed to the fact that the influent ammonia loading was relatively high. Hodge and Devinny ${ }^{[16]}$ observed that the EBRT had no significant effects on ammonia removal, which primarily may be due to the large capacity $(9.50 \mathrm{~L})$ of the biofilter, which absorbs high ammonia load. 


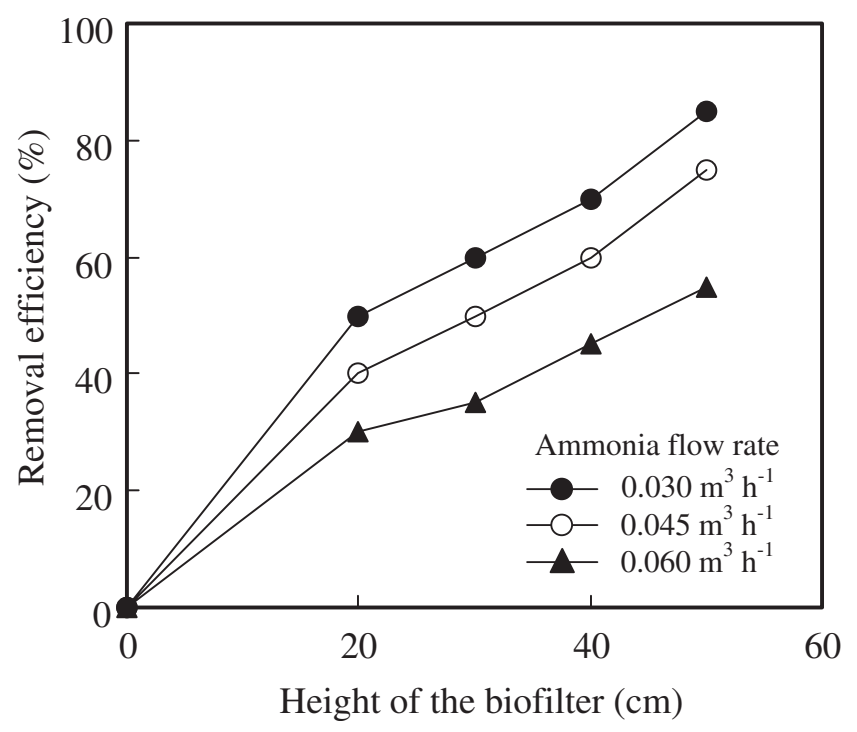

Figure 4. Removal efficiency of the second biofilter (peat and polystyrene spheres) at different bed heights for $200 \mathrm{ppmv}$ ammonia in between $23-32^{\circ} \mathrm{C}$.

\section{Peat and Polystyrene Spheres}

Desshusses et al. ${ }^{[17]}$ used compost and polystyrene spheres as packing material in biofilters for the degradation of methylethyl ketone and methyl isobutyl ketone resulting in $98 \%$ removal efficiency. Keeping this in view, we selected $3 \mathrm{~mm}$ polystyrene spheres as packing and supporting material for our second reactor. The characteristic presentation of the second type of biofilter is shown in Fig. 4 where the removal efficiencies are plotted against the depth of the biofilter. Apparently, the removal efficiency shows a discrete deviation along the height of the filter.

At a gas concentration of $200 \mathrm{ppmv}$ with flow rate of $0.030 \mathrm{~m}^{3} \mathrm{~h}^{-1}$ when passed through a bed height of $50 \mathrm{~cm}$ eliminated only $85 \%$ of ammonia when compared to the first reactor indicating a reduction in biodegradation levels. Only 55\% removal was achieved at a gas flow rate of $0.060 \mathrm{~m}^{3} \mathrm{~h}^{-1}$ at the same bed height indicating a $25 \%$ decrease in the removal efficiency when compared to the first type reactor.

When the filter bed height was more than doubled, the removal efficiency did not double at various identical flow rates indicating a constraint over optimal microbial metabolic activity and their corresponding catalytic (degradative) activity, which is highly governed by the presence of sufficient moisture content. Since the supporting matrix (polystyrene spheres) is hydrophobic, their incapability to provide moisture to microbes perhaps explains the immoderate reduction in removal efficiency in this second reactor.

Martens et al. ${ }^{[18]}$ conducted similar studies by using packing materials designed by biochips coconut-peat, wood bark pellets and compost as packing and supporting materials for microbial anchorage. His reports indicate a reduction in microbial population in the biofilters over a period followed by a reduction in ammonia 
assimilation, which could be due to the non-availability of adequate moisture levels to support the formation of biofilm primarily responsible for the assimilation of ammonia. Melvin et al. ${ }^{[19]}$ studied gaseous ammonia removal in laboratory-scale biofilters (14-L reactor volume) containing perlite inoculated with a nitrifying enrichment culture. These biofilters received $6 \mathrm{~L} \mathrm{~min}^{-1}$ of airflow with inlet ammonia concentrations of 20 or 50 ppmv, and removed more than $99.99 \%$ of the ammonia for 102 days. We were able to achieve the same removal efficiency in a biofilter with less than $1 \mathrm{~L}$ capacity at a inlet gas flow rate of $0.030 \mathrm{~m}^{3} \mathrm{~h}^{-1}$ at $200 \mathrm{ppmv}$ concentration.

Peat, Perlite, and Vermiculite on Removal 400 ppmv Ammonia

Comparing the first and second biofilter the performance of the former was superior to the later so the same was used for our further investigations. Immediate irritation of eyes, nose and throat occurs at $400-700 \mathrm{ppm}$ of ammonia causing edema, dyspnoea, bronchospasm, and chest pain, pink frothy sputum. ${ }^{[20]}$ U.S. Navy Standards [U.S. Bureau of Ships 1962] Maximum allowable concentrations (MACs): continuous exposure to ammonia for 60 days is $25 \mathrm{ppmv}$ and $1 \mathrm{~h}$ is $400 \mathrm{ppmv} .^{[21]}$ considering these facts, we choose to study the biodegradation effect of $400 \mathrm{ppmv}$ of ammonia at different flow rates in the first biofilter. A maximum of $65 \%$ removal efficiency was achieved at a height of $50 \mathrm{~cm}$ of packed bed height at a flow rate of $0.030 \mathrm{~m}^{3} \mathrm{~h}^{-1}$ with an elimination capacity of $1.414 \mathrm{~g} \mathrm{~m}^{-3} \mathrm{~h}^{-1}$ (Fig. 5). When the flow rate was increased to $0.060 \mathrm{~m}^{3} \mathrm{~h}^{-1}$ the removal efficiency was only $25 \%$. It is evident that as the perfusion column height is increased the removal efficiency also increases by approximately $10 \%$. When comparing the maximum removal efficiencies at 200

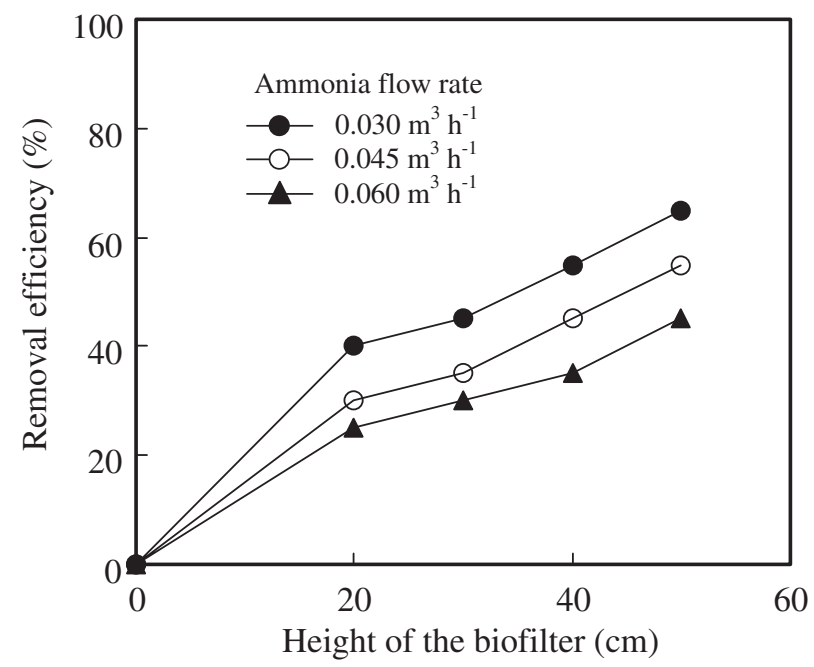

Figure 5. Removal efficiency of the first biofilter (peat, perlite, and vermiculite) at different bed heights for $400 \mathrm{ppmv}$ ammonia in between 23 and $32^{\circ} \mathrm{C}$. 
and $400 \mathrm{ppm}$ ammonia concentrations, a reduction in biodegradation levels by $35 \%$ was observed in this first biofilter.

This primarily could be due to the high load of ammonia falling on the biofilm causing a degradation constraint on the bioprocess. Indirectly, fluctuating temperatures and moisture can also hamper the biodegradation process. Probably by gaining control over these parameters and by increasing the cross section area of the perfusion column, higher removal efficiency can be achieved.

A three-stage laboratory system, i.e., two biofilters in series followed by a liquid phase anaerobic reactor to treat leachate from the second biofilter, was designed to biodegrade acrylonitrile to ammonia, convert the ammonia to nitrate and then reduce the nitrate to nitrogen gas has recently been reported. ${ }^{[22]}$ When considering dual reactors for treatments processes, our observation towards cost benefit evaluation is not appreciably high which affects the operation economics.

\section{Stability of Biofilter Performance}

A major problem associated with waste gas treatment operations is the variability in the flow and the concentrations in the effluent. Hence any practical waste treatment should be able to allow such fluctuations. The performance of any biofilter strongly depends upon the stability and the formation of the biofilm inside the biofilter. To study the stability of the biofilm in the biofilter, the transient behavior of the shut down and restart operation were investigated. With an initial ammonia concentration of $200 \mathrm{ppmv}$ at a gas flow rates of $0.030,0.045$, and $0.060 \mathrm{~m}^{3} \mathrm{~h}^{-1}$, respectively, the biofilter was shut down for 30 days and re-started. Ammonia removal efficiency of the biofilter resumed immediately (Fig. 6) without any loss, neither in efficiency nor in their buffering capacity.

This confirms that the biofilm developed inside the biofilter was quite stable and the biodegradative activity of the chemolithotrophic microorganism in the biofilter is restored completely. During the shut down, the activity of the biomass in the biofilter might have been maintained by the peat moss in the biofilter.

\section{Removal Mechanisms}

Ammonia is readily absorbed in water followed by transition from gas phase to liquid phase evolving heat energy (exothermic reaction). Ammonia in the gas phase through passive diffusion crosses the aqueous biofilm and then into the partially permeable membrane of those acclimated gram-negative chemolithotrophic microorganisms. These microbes obtain energy from oxidation-reduction reactions of ammonia using it as a nitrogen source or they degrade ammonia through nonspecific enzymes regulated inside the mitochondria located in the protoplasm. These microbes oxidize ammonia to nitrite and then to nitrate. Earlier reports indicate that the glutamate synthase and glutamate synthetase pathway are the only way of ammonia assimilation.

Ammonia removal during the start-up period was mostly due to the adsorptive capacity of the filter material as the initial biomass concentration is low and 


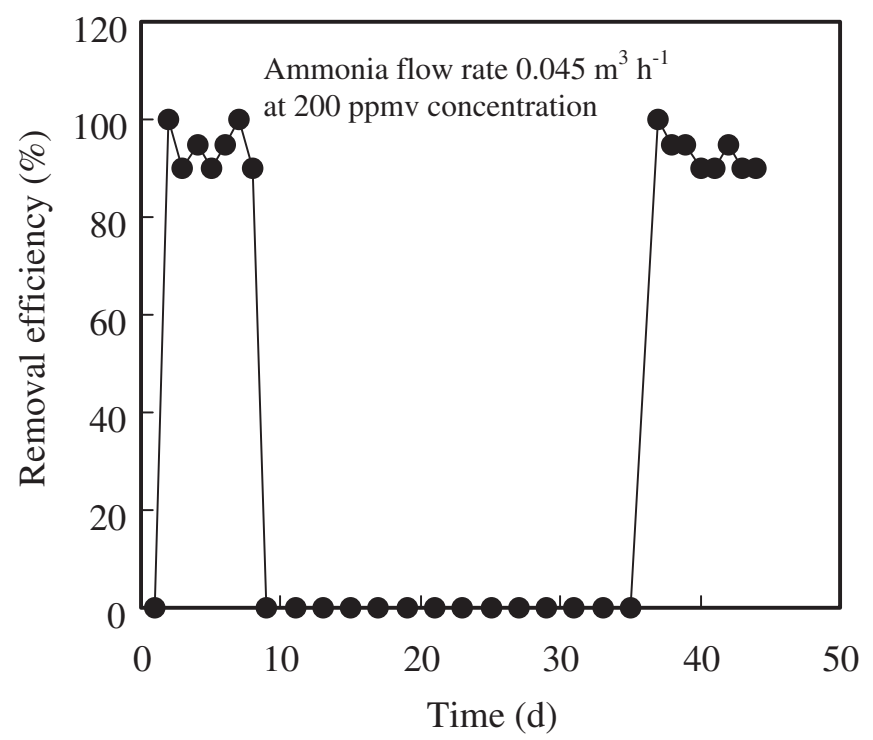

Figure 6. Response of the first biofilter (peat, perlite, and vermiculite) to one month shut down and re-start-up operation ranging in between 23 and $32^{\circ} \mathrm{C}$.

biodegradation cannot account for the complete removal of ammonia. As the biofilm is formed over the filter material, however, the removal mechanism shifts towards biodegradation. Similar observation is being observed by Dennis Mcnevin et al. ${ }^{[23]}$ and Gilmore et al. ${ }^{[24]}$

After establishment of a biofilm, the feed ammonia and the gas flow rate were varied to study the performance of the biofilter for the removal of ammonia. Removal efficiency is the critical parameter, used to estimate the successful accomplishment of the biofilter.

The mechanism underlying for the degradation could be that when ammonia switches from gas phase to liquid phase and dissolves in the biofilm, it is oxidized through the insertion of one atom of oxygen, (derived from $\mathrm{O}_{2}$,) to hydroxyl-amine $\left(\mathrm{NH}_{2} \mathrm{OH}\right)$. In the presence of elemental copper, this reaction is catalyzed by ammonia mono-oxygenase located in the cell membrane. In the presence of iron hydroxylamine is reduced to nitrite by hydroxylamine reductase and further reduced to nitrate by nitrite reductase, which is a iron-sulfur molybdenum flavoprotein. During these three catalytic reactions a stream of hydrogen ions are released inside the biofilm that permeates through the bacterial cell membrane inducing the formation of adenosine triphosphate (ATP).

These hydrogen ions permeate through a channel in an ATP synthase complex of proteins located in the membrane of the bacteria. Electron carriers use the energy to transfer hydrogen ions across membrane, and against a concentration gradient. ATP synthase also functions as a reservoir and harnesses the exergonic flow of hydrogen ions to drive the phosphorylation of ATP. To maintain the concentration gradient, energy is consumed and the same in the form of potential energy is stored. ATP 
synthase in the membrane of bacteria uses this energy to make ATP thus generating energy for cellular activities and growth. Perhaps this could be a possible mechanism bioengineered by chemolithotrophs for effective ammonia degradation process and energy derivation. A third class of nitrifiers includes the anaerobic ammonium oxidizers. They use the so-called 'anammox' process, which is the oxidation of ammonium coupled to the reduction of nitrite and yields molecular nitrogen. It has been shown that this is a biological process but the exact mechanism is not elucidated yet.

\section{SUMMARY AND CONCLUSIONS}

Biodegradation in biofilter containing peat, perlite, and vermiculite at the specified proportions as the main biomass support appears to be cost effective treatment method for ammonia. Concentrations as high as $200 \mathrm{ppmv}$ could be completely degraded at a gas flow rate of $0.030 \mathrm{~m}^{3} \mathrm{~h}^{-1}$ in a fluctuating room temperature condition. Higher gas flow rates did not significantly reduce the removal efficiency, which is mainly governed by mass transfer limitations and shorter residence times. Our studies have shown that by the addition of perlite and vermiculite the frequent addition of water to maintain moisture content in biofilter is partially eliminated.

At an influent ammonia concentration of $200 \mathrm{ppmv}$ at a flow rate of $0.030 \mathrm{~m}^{3} \mathrm{~h}^{-1}$, when perfused through this biofilter with a bed height of $50 \mathrm{~cm}$; a permissible limit of 1 ppmv of ammonia emission standards specified by Taiwan's Environmental Protection Agency (EPA) could easily be achieved. The maximum $(100 \%)$ ammonia removal efficiency was obtained in the first biofilter (peat, perlite and vermiculite) which held an elimination capacity of $2.217 \mathrm{~g} \mathrm{~m}^{-3} \mathrm{~h}^{-1}$ which is comparable to the elimination capacities reported in the literature. At an influent ammonia concentration of $400 \mathrm{ppmv}$ at a flow rate of $0.030 \mathrm{~m}^{3} \mathrm{~h}^{-1}$, when perfused through the same biofilter with a bed height of $50 \mathrm{~cm}$, only $65 \%$ removal was achieved.

The transient response of the biofilter to shut down and re-start-up showed that the biofilm has a good stability. The removal efficiency of ammonia ranged from 98 to $100 \%$, which is equal or higher than the reported values in literature. Tests indicate that the lifetime of the filter media exceeded three months and predictably may well extend beyond nine months.

\section{ACKNOWLEDGMENTS}

The authors wish to acknowledge the financial support of the National Science Council of Republic of China under Grant NSC 91-2313-B002-025.

\section{REFERENCES}

1. Hartung, J.; Phillips, V.R. Control of gaseous emissions from livestock buildings and manure stores. Journal Agric. Eng. Res. 1994, 57, 173-189. 
2. Heber, A.J.; Duggirala, R.K.; Ni, J.Q.; Spence, M.L.; Haymore, B.L.; Adamchuk, V.I.; Bundy, D.S.; Sutton, A.L.; Kelly, D.T.; Keener, K.M. Manure treatment to gas emissions from large swine houses. In International Symposium on Ammonia and Odor Control from Animal Production Facilities; Voermans, J.A.M., Monteny, G.J., Eds.; Vinkeloord: The Netherlands, 1997; 449-458.

3. Groenstein, C.M. Welfare friendly housing and ammonia emissions. Pig Prog. 2000, 16, 27-30.

4. Sutton, A.L.; Kephart, K.B.; Verstegen, M.W.A.; Canh, T.T.; Hobbs, P.J. Potential for reduction of odorous compounds in swine manure through diet modification. Journal Animal Sci. 1999, 77, 430-439.

5. Council of Agriculture, Executive Yuan of Republic of China. Food Production and Activities in Taiwan Area; 2001; 19-26.

6. Raddon, K.; Blainey, D.; Blainey, J.; Danuser, B.; Iverson, M.; Monso, E.; Opravil, U.; Weber, C.; Nowak, D. Respiratory Symptoms in European Pig Farmers, International Symposium on Dust Control in Animal Production Facilities, Aarhus, Denmark, 1999; 176-177.

7. Donaham, K. A Historical Overview of Research on the Hazards in Dust in livestock Buildings, International Symposium on Dust Control in Animal Production Facilities, Aarhus, Denmark, 1999; 13-21.

8. Swanson, J.W.; Loehr, R.C. Biofiltration: fundamentals, design and operations principles and applications. Journal Environ. Eng. 1997, 123, 538-546.

9. Luo, J. A pilot-scale study on biofilters for controlling animal rendering process odour. Water Sci. Technol. 2001, 44, 277-285.

10. Chung, Y.C.; Huang, C.; Tseng, C.P. Biotreatment of ammonia from air by immobilized Arthrobacter oxydans CH8 biofilter. Biotechnol. Prog. 1997, 13, 794-798.

11. Chung, Y.C.; Huang, C. Biotreatment of ammonia in air by immobilized Nitrosomonas europeae biofilter. Environ. Prog. 1998, 17, 70-76.

12. Chung, Y.C.; Huang, C.P.; Tseng, C.P.; Pan, J.R. Biotreatment of $\mathrm{H}_{2} \mathrm{~S}-$ and $\mathrm{NH}_{3}$-containing waste gases by co-immobilized cells biofilter. Chemosphere 2000, 41, 329-336.

13. Heber, A.J.; Ni, J.O.; Lim, T.T.; Sutton, A.L. Field Tests of “Alliance," Final Report to Monsanto; Envirochem, Purdue University, 1998; 266.

14. Ni, J.Q.; Hendriks, J.; Vinckier, C.; Coenegrachts, J. A new concept of carbon dioxide accelerated ammonia release from liquid manure in pig house. Environ. Int. 2000, 26, 97-104.

15. Miller, M. Ammonia rules move ahead in North Carolina. Pork 2000, 11, 12.

16. Hodge, D.S.; Devinny, J. Modeling removal of air contaminants by biofiltration. Journal Environ. Eng. 1995, 121, 21-44.

17. Desshusses, M.A.; Geoffrey, H.; Dunn, I.J. Transient-state behavior of a biofilterremoving mixture of vapour of MEK and MIBK from air. Biotech. Bioeng. 1996, 49, 587-598.

18. Martens, W.; Martinec, M.; Zapirain, R.; Stark, M.; Hartung, E., Palmgren, U. Reduction potential of microbial, odour and ammonia emissions from a pig facility by biofilters. Int. Journal Hyg. Environ. Health 2001, 203, 335-345. 
19. Melvin, S.F.; Joshi, J.A.; Hogan, J.A.; Cowan, R.M.; Strom, P.F. Biological removal of gaseous ammonia in biofilters: space travel and earth-based applications. Journal Air \& Waste Manage. Assoc. 2000, 50, 1647-1654.

20. DeBoer, S.; Morrison, W.D. The Effects of the Quality of the Environment in Livestock Buildings on the Productivity of Swine and Safety of Humans; A Literature Review, University of Guelph, 1988.

21. Henderson, Y.; Haggard, H.W. Noxious Gases and the Principles of Respiration Influencing their Action, Chemical Catalogue, 2nd Edn.; Reinhold Publishing Corporation: New York, 1943.

22. Yamashita, S.; Kitagawa, M. New Biofiltration System for Emission Control of Waste as Containing Acrylonitrile, Proceedings of the 94th Annual Meeting of the Air and Waste Management Association, Orlando, FL, 2001 Paper 193.

23. Mcnevin, D.; Barford, J.; Hage, J. Adsorption and biological degradation of ammonium and sulfide on peat. Water Res. 1999, 33, 1449-1459.

24. Gilmore, K.R.; Husovitz, K.J.; Holst, T.; Love, N.G. Influence of organic and ammonia loading on nitrifier activity and nitrification performance for two stage biological aerated filter system. Water Sci. Technol. 1999, 39, 227-234.

Received June 19, 2003 


\section{Request Permission or Order Reprints Instantly!}

Interested in copying and sharing this article? In most cases, U.S. Copyright Law requires that you get permission from the article's rightsholder before using copyrighted content.

All information and materials found in this article, including but not limited to text, trademarks, patents, logos, graphics and images (the "Materials"), are the copyrighted works and other forms of intellectual property of Marcel Dekker, Inc., or its licensors. All rights not expressly granted are reserved.

Get permission to lawfully reproduce and distribute the Materials or order reprints quickly and painlessly. Simply click on the "Request Permission/ Order Reprints" link below and follow the instructions. Visit the U.S. Copyright Office for information on Fair Use limitations of U.S. copyright law. Please refer to The Association of American Publishers' (AAP) website for guidelines on Fair Use in the Classroom.

The Materials are for your personal use only and cannot be reformatted, reposted, resold or distributed by electronic means or otherwise without permission from Marcel Dekker, Inc. Marcel Dekker, Inc. grants you the limited right to display the Materials only on your personal computer or personal wireless device, and to copy and download single copies of such Materials provided that any copyright, trademark or other notice appearing on such Materials is also retained by, displayed, copied or downloaded as part of the Materials and is not removed or obscured, and provided you do not edit, modify, alter or enhance the Materials. Please refer to our Website User Agreement for more details.

\section{Request Permission/Order Reprints}

Reprints of this article can also be ordered at http://www.dekker.com/servlet/product/DOI/101081PFC120027448 